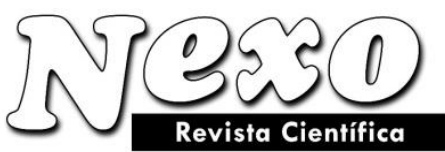

Vol. 34, No. 01, pp. 431-437/Marzo 2021

\title{
Economic and legal mechanism for the service enterprise operation
}

\section{Mecanismo económico y legal para la operación de la empresa de servicios}

\author{
Olga Vladimirovna Dmitrieva ${ }^{1, *}$, Viktoria Borisovna Frolova ${ }^{2}$, Lyubov Mikhailovna Tyger $^{3}$, \\ Valery Anatolyevich Zokoev ${ }^{4}$, Konstantin Mikhailovich Ivanov ${ }^{4}$ \\ ${ }^{1}$ Moscow Polytechnic University, Moscow, Russia. \\ ${ }^{2}$ Finance University under the Government of the Russian Federation, Moscow, Russia. \\ ${ }^{3}$ Russian State University of Tourism and Service, Moscow, Russia. \\ ${ }^{4}$ Saint-Petersburg University of State Fire Service of the Ministry of the Russian Federation for Civil \\ Defense, Emergencies and Elimination of Consequences of Natural Disasters, Saint Petersburg, Russia \\ *ovdmitrieva@yandex.ru
}

(recibido/received: 13-November-2020; aceptado/accepted: 07-January-2021)

\begin{abstract}
The article is dedicated to developing an economic and legal mechanism for the service enterprise operation. It has been determined that the components of the economic management mechanism of a service enterprise are economic and legal mechanisms that are closely interconnected. It has been revealed that the economic mechanism lies behind the economic management and determines the deep objective basis of this phenomenon. It reflects the combination of economic, organizational, and administrative levers, and methods that regulate organizational and technical, service and technological, financial and economic processes and relations for the efficient results of a business entity in the current context. It has been proved that when determining the form of a service enterprise, it is necessary to define its meaningful individuality according to the legislation and to recognize this form as the basis for classif ying such subjects into types within the relevant generic concepts thereto.
\end{abstract}

Keywords: economics, law, service enterprise, mechanism, crisis, management, instrument, lever.

\section{RESUMEN}

El artículo está dedicado a desarrollar un mecanismo económico y legal para la operación de la empresa de servicios. Se ha determinado que los componentes del mecanismo de gestión económica de una empresa de servicios son mecanismos económicos y legales que están estrechamente interconectados. Se ha revelado que el mecanismo económico está detrás de la gestión económica y determina la base objetiva profunda de este fenómeno. Refleja la combinación de palancas económicas, organizativas y administrativas, y métodos que regulan los procesos y relaciones organizativas y técnicas, de servicio y tecnológicas, financieras y económicas para los resultados eficientes de una entidad empresarial en el contexto actual. Se ha demostrado que al determinar la forma de una empresa de servicios, es necesario definir su individualidad significativa de acuerdo con la legislación y reconocer esta forma como la base para clasificar tales sujetos en tipos dentro de los conceptos genéricos relevantes de la misma. 
Palabras clave: economía, derecho, empresa de servicios, mecanismo, crisis, gestión, instrumento, palanca.

\section{INTRODUCTION}

The crisis state of the national economy, being inherent to the market environment, induces service enterprises to promptly find any new ways and reserves to develop themselves permanently. This requires the creation of systems for managing and organizing technological processes to ensure their efficient services, stability, and ability to quickly respond to any external changes.

To develop a proper economic and legal mechanism for efficient operation, it is necessary to thoroughly study this category, i.e., its constituent elements with their relations and the efficiency in the competitive environment. This mechanism is also exposed to the enterprise's internal and external factors that determine the complexity of such study of its components and exposure methods. At the same time, the mechanism as a system of levers and instruments for achieving the goal acts as a determining factor of efficient performance.

The problems related to such operation were described in detail in the works of A.A. Vitorshkina (2019), N.I. Danilenko, E.S. Zambrzhitskaya, E.D. Yachmeneva (2020), M.M. Kiseleva, O.V. Zubareva (2019), M.G. Nazarova (2020), A.V. Rusheva (2019), A.D. Shmatko, N.D. Bystrov, V.Yu. Gorbunov (2019), etc. These authors considered the essence of management, organizational, economic and legal mechanisms, and their role in ensuring the competitiveness of services. However, the problems related to the structure of such economic and legal mechanism, its main components, and methodological approaches to assessing its efficiency are still to be solved.

\section{METHODS}

Theoretically and methodologically the study was based on the abstract and logical method, the methods of induction, deduction, analysis, synthesis, and systematization for substantiating the approaches to developing the economic and legal mechanism for the service enterprise operation, and the graphical method for studying the development rate and trends.

In terms of information, the study was based on the state agency data, laws, and standards regulating the operation and policy of service enterprises, as well as the research results (Agamirova et al., 2017; Lobanov et al., 2020; Ogloblina et al., 2020).

It is planned to describe the components of the economic and legal mechanism for the service enterprise operation that refer to a variety of economic and legal instruments, to form criteria for developing a service enterprise, and to create a criteria approach to developing a service system for visualizing and assessing the activity in the crisis.

\section{RESULTS}

According to the study results, the economic management mechanism of a service enterprise includes economic and legal mechanisms that are closely related. The economic mechanism underlies the operation of the economic management mechanism and determines the objective basis of this phenomenon, reflects the combination of economic and organizational and administrative levers and methods regulating organizational, technical, service and technological, financial and economic processes and relations for the efficient results. 
As for the legal mechanism, it is necessary to note that it is closely related to the organizational, economic, and social mechanisms because it regulates the activities of economic entities, their rights, obligations, and responsibilities to other economic subjects. Therefore, the interaction of these two mechanisms is a factor in improving the economic management mechanism of a service enterprise, as a whole, and its components, in particular.

Consequently, the economic and legal mechanism can cause the expected result only when it takes into account all economic interests within the legal framework, and efficiently combines the above. At the same time, taking into account the study results, it is possible to conclude that the economic mechanism for the service enterprise operation is a set of the levers that determine the nature of the interaction among systems of management, production, marketing, and logistics, whose efficiency depends on the methods chosen for managing its economic resources.

In the long run, this determines the position of a service enterprise and the success in achieving its goals. The constituent elements of the economic mechanism are a system of levers, methods, and objects. This system cannot be absolute or traditional. Each component of the mechanism structure must be properly implemented at all levels and it has a systemic and complex nature. Moreover, when analyzing the economic mechanism structure, it is necessary to note that a system of economic levers and methods aimed at the interaction of enterprise objects must be considered as an integral part thereof.

In the course of social development, i.e., improving the technological capabilities and the system of service relations, and expanding the combination of socio-economic needs based thereupon, the number of levers and methods that influence the efficient performance, and the economic mechanism as a whole, is growing. These levers are an obligatory component of the economic mechanism because they combine the mechanism components into a single system and ensure the system integrity.

However, the levers cannot solve problems by themselves, as they have no close relations that make them only a means for achieving the goal of a service enterprise. Therefore, to use such levers, one should rely on the system of applicable legal norms.

From this point of view, the authors suggest referring the legislative and regulatory framework, as well as the methodological support for service enterprise's activities to the methods of the economic mechanism for its operation, because it is possible to regulate and bring an organized system into action only by using the implemented available elements. In this case, the efficiency of the service enterprise operation largely depends on the proper use of the economic mechanism methods.

The use of these methods ensures compliance with legal norms and powers when resolving issues of service activities, as well as the use of coercive measures and disciplinary liability. Thus, the methods of economic management are a set of measures, methods, and techniques aimed at creating favorable conditions for the efficient operation and development of elements of the economic mechanism for the service enterprise operation.

At the same time, to operate efficiently, a service enterprise must determine and organize numerous interrelated activities, because it can achieve success only subject to the efficient use of resources and the accurate interaction of functional systems during service activities related to using fixed assets, working capital, financial resources, and selling services and making a profit, fulfilling contractual obligations and improving the economic efficiency of service activities.

Due to this, the authors identified objects of the economic mechanism of a service enterprise whose efficiency and use undergo the impact of the levers and methods of the mechanism. The latter include such functional systems as the production of services, marketing, logistics, and management, as well as 
resources associated with the economic mechanism for the service enterprise operation: material, intangible, labor, information, innovation, and investment (Figure 1).

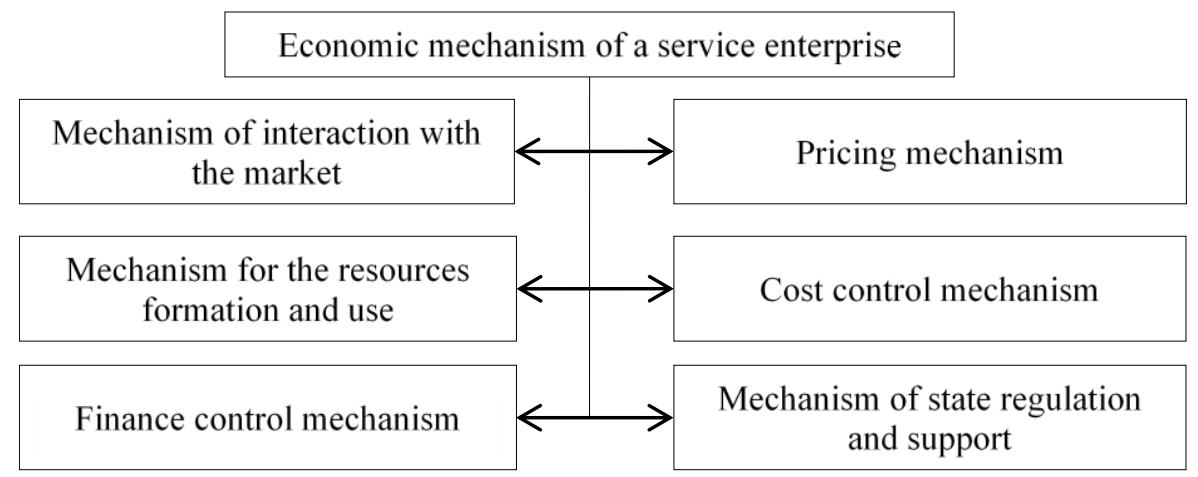

Figure 1. Structure of the Economic Mechanism of a Service Enterprise

According to the studies, only the optimal interrelation of all elements of the economic mechanism of a service enterprise will trigger the universal mechanism for its efficient operation. The formation of such a mechanism will allow a service enterprise to achieve the maximum efficiency in economic and social terms following the optimally selected management decision.

At the same time, the economic mechanism for the service enterprise operation aims at ensuring coordinated interaction of levers, methods, and objects to achieve the set goals with the least loss of financial, material, and labor resources in the strategic and operational periods. The economic mechanism of a service enterprise as a system will operate efficiently only if all its subsystems are directed not only to achieve the current ones but also to fulfill a strategic task that provides for the development of a service enterprise in the future, taking into account its current state.

It is necessary to note that any mechanism, including the economic one, has a driving force that sets on its components ensuring its development. Such a driving force includes the needs of human society, both individual and social. A service enterprise is also forced to adhere to the economic aspects of development by the fact that the resources used by the society are limited, while its needs are unlimited.

The economic mechanism of a service enterprise should aim at meeting these needs, because the strive to meet these needs sets it on, and forces it to develop, taking into account the availability and cost of the required resources. Consequently, the economic mechanism for the service enterprise operation must be constantly improved.

At the same time, the main task is to timely identify its weak points, make appropriate adjustments, clarifications, and strengthen its impact on improving efficiency and quality. The task of the economic mechanism of a service enterprise is the following: being based on economic laws and mechanisms of their performance and using the achievements of scientific and technological progress, to organically combine the methods and levers of economic management into one system and to improve the efficiency of objects of this mechanism in the conditions of instability.

The practice has shown that when determining forms of service enterprises, the legislator singles out their substantive individuality, defined by the legislation, and at the same time recognizes the form as the basis for classifying these entities into types within the generic concepts corresponding to them. These forms are the legal documentation of organizational and other characteristics of a service enterprise in modern conditions. The determination of the mechanism of legal regulation of a service enterprise makes it 
possible to make limited judgments about its content, i.e., constituent species characteristics, manifested in the form (Figure 2).

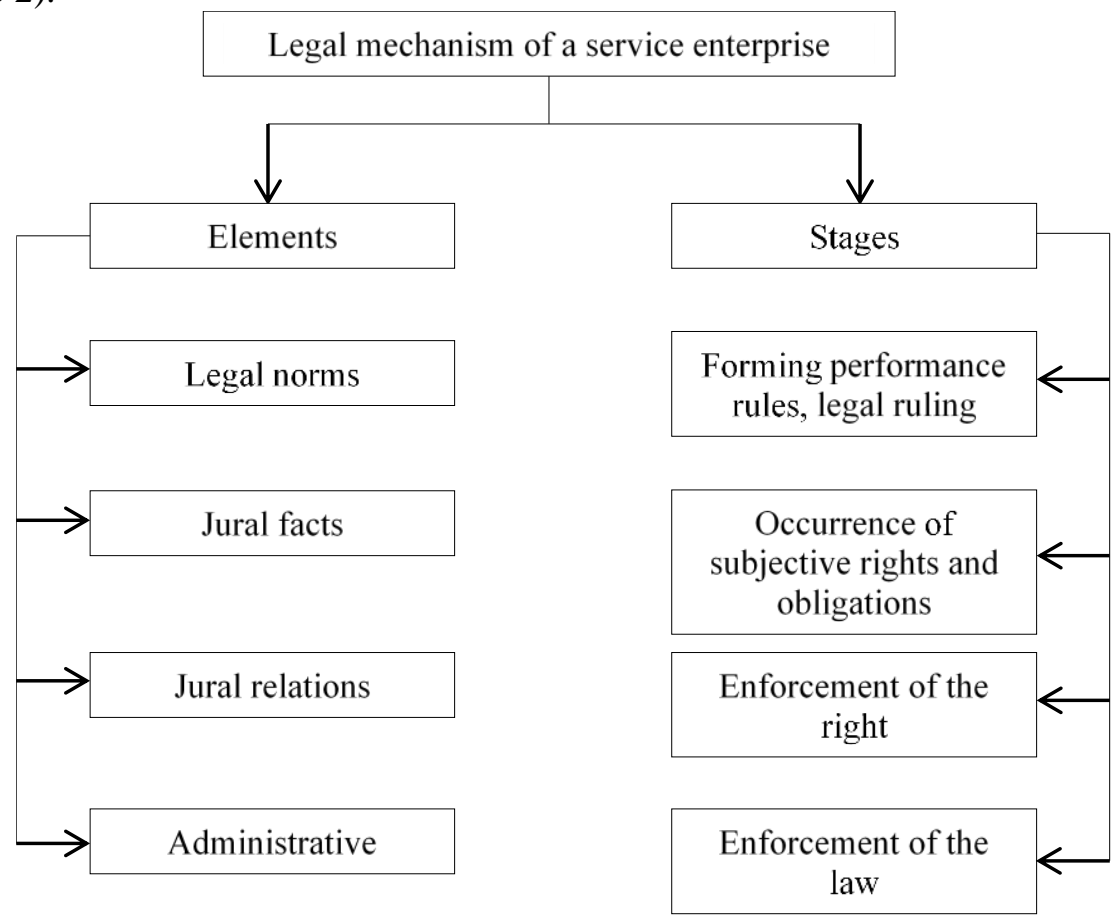

Figure 2. Structure of the Legal Mechanism of a Service Enterprise

It would be preferable to use a more specific term - a form of a commercial (noncommercial) service organization instead of the term organizational and legal form of a service enterprise. The correct use of this concept is of undoubted practical importance. Certain types of commercial and noncommercial service enterprises are marked with the characteristics inherent in each of them. The characteristics found in one form of commercial service enterprise are not necessarily found in another. Therefore, it is possible to interpret the organizational and legal form as the way of securing and using the property by a service enterprise and its resulting legal status and goals of the entrepreneurial activity.

One of the essential characteristics inherent in all types of commercial and noncommercial service enterprises is the entrepreneurial activity they carry out. However, for noncommercial service enterprises, this is rather an exception. Otherwise, the line between commercial and noncommercial service businesses is blurred.

Since the judicial practice has limited the number of subjects of the right of economic management to unitary enterprises, it is necessary to acknowledge that the method of securing property is a characteristic of a form of a commercial (noncommercial) service enterprise. However, the method of using the property is determined exclusively by the owner of this property and is carried out within the limits established by law, and therefore it cannot be in any way related to the form of a service enterprise.

Before analyzing the correlation between a service enterprise and its legal form, it is necessary to dwell on the problem related to determining the status of a service enterprise in law. Scientific discussions on this topic have their history, and they are based on an ambiguous interpretation of the status of a service enterprise in the law. It is based on two points of view the law has as for the content of the concept of a service enterprise - as an object of law and as a subject of law. 
At the same time, the legislation, recognizing a service enterprise as a subject of civil legal relations, does not put into this concept the meaning that a service enterprise is interpreted as an economic entity. In this case, a service enterprise is a commercial organization that has generic and specific characteristics inherent in it.

A service enterprise, carrying out activities on the production of services, acts as an economic entity in the economic turnover, which indicates the groundlessness of the legislative substitution of the concept of enterprise by the construction of a legal entity. A service enterprise, carrying out its activities, acquires a certain organizational structure, which causes interest in the existing criteria for its choice. These criteria are determined by the transaction costs of the activity and requirements of the law

\section{DISCUSSION}

The reliability of the above approaches is confirmed by the fact that the characteristics of the economic and legal mechanism for the service enterprise operation made it possible to determine that when forming it by service enterprises, it is necessary to observe certain principles, including the provision of an efficient combination of all elements of the mechanism and the assessment of the system quality and feedback in the management system (Frolova, Borisova, Filimonova, 2020; Lukiyanchuk et al., 2020; Zavalko et al., 2017).

It is necessary to note that service enterprises have sufficient independence for management, which allows them to show economic initiative, take economic decisions, and carry out efficient activities based on the determined interests. All this is typical for any business entity. However, the mechanism elements and their interrelation are to be concretized by the area of service activities, i.e., before analyzing the economic and legal mechanism for the service enterprise operation, it is necessary to clarify the essence of its main elements.

Since the economic and legal mechanism for the service enterprise operation is a complex category with mainly unstable internal and external relations, it is difficult to determine the efficiency of its operation as a whole, because the integral and unified assessment methodology has not been formed.

The study results indicate that the most appropriate assessment of this mechanism should be carried out by using the methodological approach based on determining the performance indicators of service, marketing, logistics, and management systems, as well as the efficiency of using the material, intangible, financial, labor, information, investment, and innovative resources. This methodology allows determining the current state of the economic and legal mechanism for the service enterprise operation to take substantiated and rational decisions on improving economic management efficiency.

\section{CONCLUSION}

Summing it up, it is possible to note that the components of the economic management mechanism for a service enterprise include economic and legal mechanisms that are closely interrelated. The economic mechanism underlies the economic management one and determines the deep objective basis of this phenomenon, as well as reflects the combination of economic and organizational and administrative levers and methods regulating organizational and technical, service and technological, financial and economic processes and relations for efficient impact on final results of the business entity in modern conditions.

At the same time, when defining forms of service enterprises, it is necessary to define their substantive individuality, specified by the legislation, and at the same time recognize the form as the basis for classifying these subjects into types within the generic concepts corresponding to them. These forms make up the legal confirmation of the organizational and other characteristics of a service enterprise. Besides, 
the definition of the legal mechanism for the service enterprise operation allows making a limited judgment on its content, i.e., its specific characteristics.

\section{REFERENCES}

Agamirova, Ek.V., Agamirova, El.V., Lebedeva, O.Ye., Lebedev, K.A., Ilkevich, S.V. (2017). Methodology of estimation of quality of tourist product. Quality - Access to Success, 18 (157), 82-84.

Danilenko, N.I., Zambrzhitskaya, E.S., Yachmeneva, E.D. (2020). Problemy avtomatizatsii uchetnyh sistem v sovremennyh organizatsiyah [Problems of Automating Accounting Systems in Modern Organizations]. Accounting in Budgetary and NonCommercial Organizations, 3 (483), 2 - 7.

Frolova, V.B., Borisova, O.V., Filimonova, N.N. (2020). Evaluation of level and growth factors of mining companies. E3S Web of conferences T.F. Gorbachev. Kuzbass State Technical University.

Kiseleva, M.M., Zubareva, O.V. (2019). Metodicheskie podkhody k otsenke effektivnosti sistemy upravlenia i ee vliyaniya na finansovoye sostoyaniye predpriyatiya [Methodological Approaches to Assessing the Efficiency of the Management System and Its Impact on the Financial Condition of the Enterprise]. Theory and Practice of Modern Science, 4 (46), 99 - 102.

Lobanov, I.V., Mudrova, S.V., Potekhina, E.V., Shelygov, A.V., Pominova, A.I. (2020). Formation of an education digitalization strategy in present-day conditions. Propositos y representaciones, 8 (S3), 777.

Lukiyanchuk, I.N., Panasenko, S.V., Kazantseva, S.Yu., Lebedev, K.A., Lebedeva, O.Ye. (2020). Development of online retailing logistics flows in a globalized digital economy. Revista Inclusiones, 7 (S2-1), 407-416.

Nazarova, M.G. (2020). Faktory, vliyayushchiye na povysheniye effektivnosti proizvodstva [Factors Influencing the Improvement of the Production Efficiency. European Science, 1 (50), 32 - 35.

Ogloblina, E.V., Seredina, M.I., Altunina, J.O., Kodolov, V.A. Lebedev, K.A. (2020). Socio-economic consequences of digital development of the economy. Revista Inclusiones, 7 (Especial), 421-430.

Rusheva, A.V. (2019). Sotsialnaya otvetstvennost biznes-resheniy [Social Responsibility of Business Decisions]. Bulletin of the Perm National Research Polytechnic University. Socio-Economic Sciences, 1, 85-99.

Shmatko, A.D., Bystrov, N.D., Gorbunov, V.Yu. (2019). Problemy funktsionirovaniya innovatsionnyh mekhanizmov upravleniya predpriyatiyem [Problems of Innovative Enterprise Management Mechanisms Functioning]. Discourse Scientific Bulletin, 5 (31), 196 - 203.

Vitorshkina, A.A. (2019). Teoreticheskie aspekty formirovaniya strategii obespecheniya ekonomicheskipravovoy bezopasnosti organizatsii [Theoretical Aspects of Forming a Strategy for Ensuring the Economic and Legal Security of an Organization]. Fundamental Science and Modernity, 7 (28), 30 - 39.

Zavalko, N.A., Kozhina, V.O., Zhakevich, A.G., Matyunina, O.E., Lebedeva, O.Ye. (2017). Methodical approaches to rating the quality of financial control at the enterprise. Quality - Access to Success, 8 (161), 69-72. 